\title{
Sound Bite Effect Dalam Komunikasi Politik
}

Oleh

\section{Husni Ritonga}

\begin{abstract}
Abstrak
Tahun politik terasa cepat bergerak lebih cepat, kendari pemilihan umum calon Presiden dilaksanakan tahun 2019 berbagai komunikasi politik pun dilakukan demi menarik simpatisan masyarakat. Akhir-akhir ini kontestasi politik sering dikait-kaitkan dengan berbagai macam ucapan-ucapan yang pada akhirnya memancing konflik sehingga perpolitikan di tanah air semakin menarik untuk dikaji, khususnya dalam kajian komunikasi politik. Segala ucapan yang disampaikan oleh para tokoh komunikasi politik dianggap sebagai suatu hal yang menarik untuk dikaji. Berbagai macam ucapan, ujaran ataupun pernyataan nyatanya bisa memberikan efek terhadap lawan bicara sehingga pesan-pesan komunikasi politik dianggap mempunyai sebuah simbol-simbol tertentu, baik secara verbal maunpun non-verbal. Kendati demikian, komunikasi politik yang disampaikan oleh para aktor politik ternyata bisa memberikan efek yang luar biasa terhadap lawan politik. Bukan hanya sekedar ucapan, bahkan gestur tubuh bisa menjadi sebuah senjata pesan politik yang dapat memberikan efek kepada lawan politik. Oleh karena dalam penelitian ilmiah ini nantinya akan membahas lebih dalam bagaimana simbol-simbol perpolitikan seperti ucapan ataupun gesture tubuh bisa memberikan efek yang luar biasa kepada lawan politik. Semua itu dilakukan untuk menarik minat masyarakat terhadap salah satu pasangan calon Presiden Republik Indonesia tahun 2019 nantinya.
\end{abstract}

Kata Kunci: Pesan Politik, Sound Bite, Berita Politik 


\section{A. Pendahuluan}

Manusia dalam keberadaannya memang memiliki keistimewaan di banding dengan makhluk yang lain. Selain kemampuan daya pikirnya, manusia juga memiliki keterampilan berkomunikasi yang lebih indah dan lebih canggih, sehingga dalam berkomunikasi mereka bisa mengatasi rintangan jarak dan waktu. Manusia menciptakan simbol-simbol dan memberi arti pada gejala-gejala alam yang ada disekitarnya, sementara hewan hanya dapat mengandalkan bunyi.

Simbol-simbol yang diciptakan manusia memiliki makna pesan tersendiri yang memiliki arti berbeda-beda tergantung oleh siapa yang membaca dan menggunakan sudut pandang mana ia menilai. Dalam komunikasi hal yang terpenting selain komunikator adalah pesan. Suatu pesan ditransformasikan pada titk-titik penyandian dan pengalihan sandi sehingga pesan merupakan pikiran dan ide pada suatu tempat pada sistem jaringan syaraf dari sumber atau penerima. Setelah penyandian terjadi dalam suatu situasi tatap muka, ditransformasikan ke dalam rangkaian getaran udara dan sinar-sinar cahaya yang terpantulkan.

Diantara bahasan yang menonjol dalam kajian Komunikasi Politik adalah menyangkut isi pesan. Bahasan ini sama pentingnya dari bahasan komunikator, media, khalayak dan efek komunikasi politik. Dalam beberapa literatur disebutkan, inti komunikasi politik adalah komunikasi yang diarahkan kepada pencapaian suatu pengaruh. Urgensinya dalam suatu sistem politik tidak diragukan lagi, karena komunikasi politik terjadi saat keseluruhan fungsi dari sistem politik lainnya di jalankan.

Makalah ini, berupaya menjelaskan dasar-dasar pesan politik baik itu ditinjau dari pengertian pesan politik, bentuk-bentuknya, teknik penyampaian pesan politik, dan media massa juga berita politik. Keempat elemen ini yang menjadi fokus pemakalah didalam pembahasan makalah. 


\section{B. Pengertian Pesan Politik}

Pesan dalam kegiatan komunuikasi membawa informasi yang disampaikan oleh komunikator. Pesan selain membawa informasi juga memberikan makna kepada siapa saja yang menginterpretasikannya. Pesan merupakan konten atau isis dari kegiatan komunikasi secara umum, termasuk komunikasi politik. ${ }^{1}$

Pesan politik merupakan salah-satu unsur penting dalam komunikasi politik. Pada hakikatnya, pesan adalah suatu informasi yang disampaikan oleh komunikator kepada komunikan yang bertujuan untuk mencari persamaan makna atau persepsi. Karena pada dasarnya pula, pesan biasanya berisikan tentang gagasan atau ide manusia untuk disampaikan bahkan untuk diperbincangkan dengan manusia lain.

Menurut Colin Cherry dalam bukunya Thomas Tokan mengatakan, suatu pesan mungkin, umpamanya, merupakan pikiran, namun pikiran ini tidak disampaikan secara fisik. Akan tetapi, bilamana bentuk fisik dari pesan ini disandi, maka berubah menjadi pikiran kembali dan karena itu menjadi pesan. Penegasan perbedaan anatara pesan dan isyarat diungkapkan juga oleh Clevenger dab Matthews. Ia membedakan antara pesan dan isyarat atas dasar bentuk fisik dan lokasinya pada saluran. Isyarat atau signal adalah peristiwa fisiknya, dan pesan hanya terdapat pada saluran di dalam diri sumber atau penerima. Dalam setiap peristiwa komunikasi terdapat tiga buah pesan yang potensial, yakni pesan yang dikirimkan, yang diterima, dan yang terjadi dalam diri pengamat situasi komunikatif itu. $^{2}$

Mengacu pada definisi komunikasi politik secara umum, pesan politik itu adalah pesan yang dibawa oleh komunikator politik, baik dalam bentuk gagasan, pikiran, ide, perasaan, sikap, maupun perilaku tentang politik yang memengaruhi komunikasi politik.

\footnotetext{
${ }^{1}$ Henry Subikato dan Rachma Ida, Komunikasi Politik, Media dan Demokrasi, ( Jakarta, Kencana Prenada Media Group : 2012 ). Hlm. 40

${ }^{2}$ Thomas Tokan, Komunikasi Politik ( mempertahankan Integritas Akademisi, politikus dan negarawan ), ( Jakarta, PT. Gramedia Pustaka Utama, 2016 ). Hlm. 43.
} 


\section{Bentuk-Bentuk Pesan Politik ( Verbal dan Nonverbal )}

Bentuk-bentuk pesan politik dibagi menjadi dua macam yaitu verbal Bahasa ) dan non verbal ( Tanpa Bahasa/simbol ) Verbal adalah bentuk komunikasi yang disampaikan komunikator kepada komunikan dengan cara tertulis (written) atau lisan (oral). Komunikasi verbal menempati porsi besar. ${ }^{3}$

\section{Pesan Verbal}

Kode verbal dalam pemakainnya, menggunakan bahasa. Bahasa dapat didefinisikan sebagai seperangkat kata yang telah disusun secara berstruktur sehingga menjadi himpunan kalimat yang mengandung arti. Bahasa mempunyai banyak fungsi, menurut Cangara bahwa bahasa mempunyai tiga fungsi yang erat hubungannya dalam menciptakan komunikasi yang efektif, yaitu untuk mempelajari tentang dunia sekeliling dan untuk membina hubungan yang baik di antara sesama manusia. ${ }^{4}$

Bahasa mengembangkan pengetahuan kita, agar kita dapat menerima sesuatu dari luar dan juga berusaha untuk menggambarkan ide-ide kita kepada orang lain. sebagai alat pengikat dan perekat dalam hidup bermasyarakat, bahasa dapat membantu kita menyusun struktur pengetahuan menjadi logis dan mudah diterima oleh orang lain. Sebab bagaimanapun bagusnya sebuah ide, kalau tidak disusun dengan bahasa yang sistematis sesuai dengan aturan yang telah diterima, maka ide yang baik itu akan menjadi kacau.

Dalam suatu kegiatan politik, bahasa sangat penting digunakan untuk menyampaikan pesan secara langsung kepada masyarakat untuk memberitahu tujuan. Bahasa verbal ini berpengaruh dalam pemaknaan khalayak yang menerima

\footnotetext{
${ }^{3}$ Hafied Cangara, Pengantar Ilmu Komunikasi, (Jakarta: PT. Raja Grafindo Persada, 1998), hlm. 25.

${ }^{4}$ Hafield Cangara, Komunikasi Politik:Konsep, Teori, dan Strategi, ( Jakarta, Rajawali Pers : 2009 ). Hlm. 95.
} 
dan memaknai pesan komunikasi yang disampaikan. ${ }^{5}$ Maka dari itu dalam komunikasi verbal ini muncul yang namanya Sound Bite culture.

Sound bite adalah satu garis kalimat yang diambil dari pidato atau pernyataan yang panjang atau seperangkat teks yang dapat digunakan sebagai indikasi dari pesan yang lebih besar. Sound bite digunakan dalam media untuk mendefinisikan pesan, argumen, dan kebijakan. Menurut Kaid dan Haltz, sound bite ini disebutnya sebagai klip atau penggalan potongan-potongan pernyataan yang penting.

Sound bite ini biasanya digunakan oleh para wartawan atau reporter karena waktu tayang yang sangat pendek. Sound bite ini sering kali menjadi kontroversi bagi para politikus, sehingga kita sering mendengar "seharusnya media menayangkan secara keseluruhan argumen agar tidak terpenggal bagian yang lain"

Kita ingat beberapa waktu yang lalu ketika gubernur Ibukota terpilih Anies Baswedan dalam pidatonya di Balai Kota sempat mengatakan kata "Pribumi"

Pesan Sound bite yang disampaikan oleh orang-orang berpengaruh seperti Anies Baswedan ini membuat banyak orang bertanya-tanya maksud dari pernyataan ini, sebagai orang Indonesia asli tentu kita tidak mempermasalahkan kata itu, namun bagi sebagian orang yang tidak keturunan asli Indonesia aka terusik dengan kata-kata Anies tadi.

\section{Pesan Nonverbal}

Kode Non-verbal

${ }^{5}$ William L. Rivers-Jay W. Jensen Theodore Peterson, Komunikasi Massa, (Jakarta: Prenada Media, 2004), h. 45. 
Manusia dalam berkomunikasi selain memakai kode verbal (bahasa) juga memakai kode non-verbal. Kode nonverbal menurut Cangara bahwa kode nonverbal bisa disebut bahasa isyarat atau bahasa diam (silent languange).

Kode nonverbal yang digunakan dalam berkomunikasi, sudah lama menarik perhatian di kalangan antropologi, bahasa, bahkan dari bidang kedokteran. Menurut Mark Knapp dalam Cangara menyebut bahwa penggunaan kode nonverbal dalam berkomunikasi memiliki fungsi:

1) Meyakinkan apa yang telah diucapkan (repetition)

2) Menunjukkan perasaan dan emosi yang tidak bisa diungkapkan dengan katakata

3) Menunjukkan jati diri sehingga orang lain bisa mengenalnya (identity)

4) Menambah atau melengkapi ucapan-ucapan yang dirasakan belum sempurna. ${ }^{6}$

Kehadiran simbol-simbol, berupa bendera, baliho, posko, dan juga massa menjadi jauh lebih penting daripada ide atau pemikiran yang disampaikan. Forum diskusi menjadi tidak menjadi tidak begitu penting sebagai sarana komunikasi politik, apalagi perdebatan politik antar-elite, yang acapkali dianggap tidak cocok secara kultural.

Komunikasi nonverbal sendiri keberadaannya sangat akrab dengan budaya masyarakat Indonesia. Peribahasa diam itu emas, tong kosong nyaring bunyinya, air beriak tanda tak dalam menyiratkan lebih menghargai bahasa nonverbal dibandingkan kecakapan bahasa lisan dalam komunikasi.

Bentuk komunikasi yang paling mendasar dan sangat menentukan dalam mempengaruhi orang lain, adalah komunikasi non-verbal. Menurut antropolog, sebelum manusia menggunakan kata-kata, mereka telah menggunakan gerakangerakan tubuh, bahasa tubuh (body language) sebagai alat untuk berkomunikasi dengan orang lain. Dalam konteks komunikasi politik, berikut ini adalah beberapa contoh perilaku yang menunjukkan komunikasi non-verbal dan sangat berpengaruh dalam meraih simpati orang lain.

\footnotetext{
${ }^{6}$ Hafield Cangara, Komunikasi Politik........... Hlm. 100.
} 
Semua atribut yang melekat pada diri seseorang menjadi alat komunikasi kepada orang lain. Seorang perempuan yang berkunjung ke kampung memenuhi undangan pernikahan memakai baju yang seksi, secara tidak langsung telah memproklamirkan diri sebagai perempuan yang kurang mematuhi etika.

Berkunjung ke pasar tradisional dengan memakai semua perhiasan akan memberi pesan kepada orang disekitar sebagai orang yang haus pujian dan selalu menganggap diri lebih hebat dibanding orang lain atau menutup pintu rumah ditengah kerumunan orang yang sedang bergotong royong membersihkan got dari ancaman nyamuk demam berdarah, menyampaikan pesan sebagai orang yang miskin jiwa sosial.

Ketiga contoh ini adalah bentuk komunikasi nonverbal. Lalu bagaimana dengan komunikasi politik, tentunya masih hangat dibenak kita walaupun sudah berlalu tentang pilkada DKI Jakarta. Banyak kita temukan komunikasi nonverbal yang dilakukan oleh pasangan calon gubernur dan wakilnya seperti baju kotakkotak.

Baju kotak-kotak ini sudah sangat identik dengan pendukung pasangan Ahok dan Djarot Saiful Hidayat, bahkan sampai sekarang ketika ada orang yang memakai baju kotak-kotak maka akan dianggap sebagai pendukung Ahok, ini adalah pesan yang sangat luarbiasa dibangun oleh pasangan Ahok dan Djarot dalam bentuk nonverbal.

Semua contoh di atas adalah komunikasi non-verbal yang sangat menentukan apakah seseorang yang ingin maju dan terpilih dalam pemilu legislatif 2014. Dalam konteks pasar demokrasi, komunikasi non-verbal memiliki pengaruh yang lebih besar daripada komunikasi verbal. Hal ini disebabkan, karena secara psikologis orang cenderung lebih mempercayai visualnya (apa yang dilihatnya). Orang akan mudah berbohong dan menipu orang lain dengan menggunakan kata-kata bahasa verbal daripada menggunakan nonverbal (bahasa isyarat). Orang cenderung apriori kepada seorang politisi yang menggunakan mobil BMW mengajak rakyat hidup sederhana. 


\section{Teknik Penyusunan Pesan Politik}

Menurut Cassandra dalam Cangara bahwa terdapat dua model penyusunan pesan, yakni penyusunan pesan yang besifat informatif dan penyusunan pesan yang bersifat persuasif.

a. Penyusunan Pesan yang Bersifat Informatif

Model penyusunan pesan yang bersifat informatif lebih banyak ditujukan pada perluasan wawasan dan kesadaran khlayak. Prosesnya lebih banyak bersifat difusi atau penyebaran, sederhana, jelas, dan tidak banyak menggunalan jargon atau istilah-istilah yang kurang populer di kalangan khalayak. Ada empat macam penyusunan pesan yang bersifat informatif, yakni:

1) Space Order, penyusunan pesan yang melihat kondisi tempat atau ruang, seperti international, nasional, dan daerah.

2) Time Order, penyusunan pesan berasarkan waktu atau periode yang disusun secara kronologis

3) Deductive Order, penyusunan pesan mulai dari hal-hal yang bersifat umum kepada khusus. Misalnya penyusunan GBHN

4) Inductive Order, penyusunan pesan yang dimulai dari hal-hal khusus ke halhal yangb bersifat umum.

Model penyusunan pesan informatif banyak dilakukan dalam penulisan berita dan artikel oleh para wartawan dengan memakai model piramid. ${ }^{7}$

b. Penyusunan Pesan yang Bersifat Persuasif

Model penyusunan pesan yang bersifat persuasif memiliki tujuan untuk mengubah persepsi, sikap dan pendapat khalayak. Sebab itu, penyusunan pesan persuasif memiliki sebuah proposisi. Proposisi disini ialah apa yang dikehendaki sumber terhadap penerima sebagai hasil pesan yang

${ }^{7}$ Ibid. Hlm. 111 
disampaikannya, artinya setiap pesan yang dibuat diinginkan adanya perubahan.

Menurut Cangara, terdapat beberapa cara yang dapat digunakan dalam penyusunan pesan yang memakai teknik persuasi, antara lain :

1) Fear Appeal, motode penyusunan pesandengan menimbulkan rasa ketakutan kepada khalayak. Sebenarnya khalayak kurang senang menerima pesan yang disertai ancaman yang menakutkan, sebab meraka tidak memiliki kebebasan untuk menentukan sikap dan mengemukakan pendapatnya. tetapi dalam hal tertentu, khalayak harus menerima karena bisa mengancam dirinya.

2) Emotional Appeal, cara penyusunan atau penyampaian pesan dengan berusaha menggugah emosional khalayak. misalnya dengan mengungkapkan masalah suku, agama, kesenjangan ekonomi, diskriminasi, dan sebagainya. Bentuk lain dari emotional appeal adalah propaganda. dalam komunikasi bisnis, propaganda banyak sekali digunakan dalam bentuk iklan, agar konsumen bisa membeli barang.

3) Reward Appeal, cara penyusunan atau penyampaian pesan menawarkan janjijanji kepada khalayak. dalam berbagai studi yang dilakukan dalam hubungannya dengan reward appel, ditemukan bahwa dengan menjanjikan uang Rp. 1 juta, seorang cenderung mengubah sikap daripada menerima janji uang Rp. 50 ribu.

4) Motivational Appeal, teknik penyusunan pesan yang dilakukan bukan karena janji-janji, tetapi disusun untuk menumbuhkan internal psikologis khalayak sehingga mereka dapat mengikuti pesan-pesan itu, misalnya menumbuhkan rasa nasionalisme atau gerakan memakai produksi dalam negeri.

5) Humoris Appeal, teknik penyusunan pesan yang dilakukan dengan humor, sehingga penerimaan pesan khalayak tidak merasa jenuh. Pesan yang disertai humor mudah diterima, enak dan menyegarkan. hanya saja dalam penyampaian pesan yang disertai humor diusahakan jangan sampai terjadi humor yang lebih dominan daripada materi yang ingin disampaikan. 
Keberhasilan dalam mengelolah dan menyusun pesan-pesan secara efektif perlu memperhatikan beberapa hal sebagai berikut :

1) Pesan yang disampaikan harus dikuasai lebih dahulu, termasuk struktur penyusunannya yang sistematis. ${ }^{8}$

2) Mampu mengemukakan argumentasi secara logis. Untuk itu harus mempunyai alasan-alasan berupa fakta dan pendapat yang bisa mendukung materi yang disajikan.

3) Memiliki kemampuan untuk membuat intonasi bahasa, serta gerakan-gerakan nonverbal yang dapat menarik perhatian khlayak. ${ }^{9}$

\section{E. Media Massa dan Berita Politik}

Bagi media massa, tugas mereka adalah menyosialisasikan pentingnya penyelesaian politik melalui pembicaraan. Apakah itu berupa yang namanya perdebatan, negosiasi, ataupun kompromi, dan lobi politik. Media massa dituntut untuk mampu menyosialisasikan toleransi ketidaksepakatan. Dan ketidaksepakatan itu dapat dinikmati sebagai buah dari demokrasi yang indah.

Media massa dituntut secara demokratis memberikan liputannya sebagai representasi opini khalayak yang beragam. Berbagai aspirasi yang diekspresikan secara verbal oleh masyarakat, kendati belum melibatkan eskalasi kekuatan yang besar, harus juga diberi tempat. ${ }^{10}$

Media massa dan pemberitaan yang ada di Indonesia seperti sudah terpetakan oleh sebagian khalayak, ada yang menganggap bahwa media massa seperti "Media Indonesia dan Metro Tv" adalah media yang bertolak belakang dengan salah satu kaum agamais terbesar dinegara ini. Seperti contoh pemeberitaan tanggal 1 Desember 2017 di Metro Tv yang menyebut aksi reuni 212 sebagai perayaan Intoleransi di Indonesia. ${ }^{11}$

\footnotetext{
${ }^{8}$ Dan Nimmo, Komunikasi Politik (Komunikator, Pesan, dan Media), (Bandung: PT. Remaja RosdaKarya, 1989), h. 167.

${ }^{9}$ Ibid. Hlm. 113

${ }^{10}$ Naniek Aprilla Framanik, Komunikasi Persuasi (Serang: Kocipta Publishing, 2012), hlm. 58 .

${ }^{11}$ www.Youtube.com/Metrotv212
} 
Mereka menyebut bahwa reuni yang dilakukan oleh kaum agamais di Indonesia ini sebagai perayaan intoleransi, pernyataan seperti ini disampaikan oleh media massa sebagai penyampai pesan politik dari kelompok tertentu untuk menyampaikan pesan politiknya.

Bahkan masyarakat sebahagian sudah tau bahwa media massa sekarang sudah ada yang mengendalikan dan tidak independen seperti dahulu, media massa digunakan sebagai senjata politik untuk mempegaruhi khalayak agar menerima pesan yang mereka sampaikan agar ikut dan terpengaruh.

\section{Kesimpulan}

Komunikasi politik yang terjadi, terutama dikalangan tokoh politik, dan beberapa kalangan elit politik masih lebih banyak dalam bentuk yang "kurang rasional". Secara empiris komunikasi politik yang berlangsung lebih diwarnai bentuk komunikasi nonverbal.

Lihat saja pilkada yang terjadi di DKI Jakarta belakangan ini, kampanye yang dilakukan sangat sedikit menyentuh persoalan kognisi politik khalayak, yang terjadi adalah eksploitasi emosi khalayak dalam pawai-pawai dan bentuk komunikasi nonverbal lainnya.

Begitu pula pada waktu sidang umum MPR tahun 1999, aspirasi masyarakat pada lembaga itu tidak diwujudkan dalam wacana perbincangan politik melalui opini publik yang kualitatif, tetapi diwujudkan dalam bentuk tekanan dengan cara kehadiran massa, pemasangan simbol-simbol politik, baik itu bendera, gambar maupun baliho.

Media juga digunakan oleh pelaku politik sebagai alat untuk menyampaikan pesan politiknya terhadap masyarakat, media juga dapat dikatakan sebagai senjata yang ampuh untuk mempengaruhi pola pimikiran masyarakat terhadap suatu isu politik yang berkembang di Indonesia. 


\section{DAFTAR PUSTAKA}

Cangara Hafield, 2009, Komunikasi Politik:Konsep, Teori, dan Strategi, Jakarta, Rajawali Pers.

Cangara, Hafied. 2009. Komunikasi Politik:Konsep, Teori, dan Strategi. Jakarta: Rajawali Pers.

Nimmo, Dan. 1989. Komunikasi Politik (Komunikator, Pesan, dan Media). Bandung: PT. Remaja RosdaKarya

Framanik, Naniek Aprilla. 2012. Komunikasi Persuasi. Serang: Kocipta Publishing,.

Henry Subikato dan Rachma Ida, 2012, Komunikasi Politik, Media dan Demokrasi, Jakarta, Kencana Prenada Media Group.

Thomas Tokan, 2016, Komunikasi Politik ( mempertahankan Integritas Akademisi, politikus dan negarawan ), Jakarta, PT. Gramedia Pustaka Utama.

William L. Rivers-Jay W. Jensen Theodore Peterson. 2004. Komunikasi Massa. Jakarta: Prenada Media.

Youtube.com 